\title{
Epidemiology of falciparum malaria among residents of some rural and peri- urban communities in Ekiti State, Southwestern Nigeria
}

\author{
Awosolu, O.B. ${ }^{1,2}$, Yahaya, Z.S. ${ }^{1 *}$, Farah Haziqah, M.T. ${ }^{1}$, Simon-Oke, I.A. ${ }^{2}$, Olanipekun, I.T. ${ }^{2}$, Oniya, M.O. ${ }^{2}$ \\ ${ }^{1}$ School of Biological Sciences, Universiti Sains Malaysia, 11800 USM, Penang, Malaysia \\ 2Parasitology and Public Health Unit, Department of Biology, Federal University of Technology, Akure, Nigeria \\ *Corresponding author: zary@usm.my
}

\section{ARTICLE HISTORY}

Received: 8 May 2020

Revised: 15 October 2020

Accepted: 16 October 2020

Published: 25 March 2021

\begin{abstract}
Malaria which is caused by parasites of the genus Plasmodium is a devastating parasitic disease of major public health challenge worldwide, particularly Nigeria. This study was carried out to investigate the epidemiology of falciparum malaria among residents of rural and peri-urban communities in Ekiti State, Southwestern Nigeria. Standard parasitological technique of microscopy was employed to determine and identify parasite prevalence and species. A questionnaire was used to collect subject's information such as age, sex, location, occupation and education. Out of the 300 individuals examined, a total of 283 (93.4\%) individuals were infected with malaria parasite. Sex pattern of infection indicated that male had higher malaria prevalence of $95.0 \%$ compared to female with the prevalence of 93.3\% ( $P>0.05)$. The age group 51 to 60 years had the highest malaria parasite prevalence of $100 \%$ while age group $<10$ years has the least malaria parasite prevalence of $86.0 \%(P>0.05)$. Similarly, a total mean malaria parasite density of 1455.90 parasite/ $\mu \mathrm{L}$ of blood was recorded. The mean malaria parasite density does not significantly vary $(P>0.05)$ among age and sex group. The age group $>60$ years recorded the highest mean parasite density of 2092.50 parasite $/ \mu \mathrm{L}$ of blood while age group $<10$ has the least mean malaria parasite density of 1044. 42 parasite/ $\mu \mathrm{L}$ of blood. In relation to sex, the highest mean malaria parasite density was found among the female (1461.80 parasite/ $\mu \mathrm{L}$ of blood) compared to male (1450 parasite/ $\mu \mathrm{L}$ of blood). In the same vein, occupation as a socioeconomic risk factor play a major role with respect to malaria infection. The highest malaria prevalence of $113(98.26 \%)$ was recorded among farmers while the least $34(85 \%)$ was recorded among Civil servants $(P<0.05)$. Thus, it is apparent that falciparum malaria is heavily prevalent in this study area and as such urgent management control measures and interventions should be made available and fully utilized.
\end{abstract}

Keywords: Ekiti State, Epidemiology, Malaria, Peri-Urban, Plasmodium falciparum, Rural.

\section{INTRODUCTION}

Malaria is a mosquito-borne protozoan parasitic disease caused by parasite of the Plasmodium genus. It is a serious global public health challenge due to its devastating and detrimental health effect coupled with social and economic consequences in the tropical and sub-tropical regions of the world particularly Nigeria. The major Plasmodium spp. in Nigeria are $P$. falciparum, $P$. vivax, $P$. ovale and $P$. malariae. In Nigeria, $P$. falciparum accounts for more than $95 \%$ of all malaria disease while $P$. ovale and $P$. malariae account for less than $5 \%$ of all malaria disease (WHO, 2016, 2017). Mixed infection with $P$. falciparum and $P$. vivax have also been recorded in Nigeria (Oboh et al., 2018). It was estimated by World Health Organization (WHO) that over half of the world's population which amounts to approximately 3.4 billion people were at risk of contracting malaria infection globally in 2017 (WHO, 2018). Furthermore, there were an estimated 228 million alarming cases and 405000 deaths due to malaria in 2018 (WHO, 2019). In sub-Sahara Africa particularly Nigeria, malaria is highly endemic and elimination of this deadly disease seems to be a mirage due to factors such as poor socioeconomic development, highly adapted mosquito vector with great vectorial capacity, lack of adequate support from government, ignorance and even drug resistance (Yeka et al., 2012; Wielgosz et al., 2014). Nigeria has the most malaria cases in Africa and worldwide in 2018 as it recorded an estimated $25 \%$ of total malaria cases worldwide (WHO, 2019). This is indeed a real cause for concern.

The epidemiology of malaria parasite includes risk factors that predispose people to malaria infection and can be basically classified into two major groups which include 
intrinsic and extrinsic factors. Intrinsic factors are inherent in human hosts and include age, sex and genotype while extrinsic are external factors such as peoples' behaviours, socioeconomic factors, climate and environmental conditions (Ghebreyesus et al., 2000; Mutero et al., 2004; Clark et al., 2008; Temu et al., 2012; Hiscox et al., 2013). Mitigating malaria requires an ongoing monitoring process and as such studies on malaria prevalence, risk factors and appropriate intervention strategy including mass distribution of insecticide mosquitoes treated bed net are highly essential. Currently, there is a dearth of information on malaria epidemiology in many parts of Ekiti State meanwhile, the few available data are becoming outdated. Thus, there is need to scale-up malaria elimination strategy in endemic regions including Ikole Ekiti. Depending on outdated information necessary for malaria control could be misleading. Therefore, there is an urgent need for adequate and updated epidemiological information upon which control could be based. Thus, this study tends to investigate the current epidemiological status of falciparum malaria among residents of some rural and peri-urban communities in Ekiti State, Southwestern Nigeria.

\section{MATERIALS AND METHODS}

\section{Ethical Approval}

Ethical approval for the study was obtained from Ondo State Ministry of Health (protocol number OSHREC/21/08/2017/012) and Ethical Review Committee of the Federal University of Technology, Akure, Nigeria. Both written and verbal informed consent was sought from all the subjects and their caregiver or guardians.

\section{Study Area}

The study was carried out in three different communities namely, Ikole-Ekiti, Asin-Ekiti and Ara-Ekiti in Ikole Local Government Area (LGA) of Ekiti State, Nigeria. Both IkoleEkiti and Asin-Ekiti are peri-urban communities while AraEkiti is a rural community. Ikole-Ekiti with a population of 168,436 is situated between Latitude $7^{\circ} 47^{\prime} 53.76^{\prime \prime} \mathrm{N}$ and Longitude $5^{\circ} 30^{\prime} 52.17 " \mathrm{E}$ while Asin-Ekiti which is less developed and populated compared to Ikole-Ekiti is situated between Latitude $7^{\circ} 47^{\prime} 24.4^{\prime \prime} \mathrm{N}$ and Longitude $5^{\circ} 29^{\prime} 26.3^{\prime \prime E}$. The distance of both Ikole Ekiti and Asin-Ekiti from Ado-Ekiti, the State capital are $49.0 \mathrm{~km}$ and $49.7 \mathrm{~km}$ respectively. Ara-Ekiti, a rural community that is poorly developed with a very small population is however situated between Latitude $7.7627^{\circ} \mathrm{N}$ and Longitude $5.1093^{\circ} \mathrm{E}$. Generally, Ikole LGA has a tropical climate with significant rainfall and a short dry season. The wet season is warm, oppressive and overcast with average annual rainfall of $1313 \mathrm{~mm}$ and the dry is not hot, humid, and partly cloudy. The average annual temperature is $24.2^{\circ} \mathrm{C}$ $\left(75.6^{\circ} \mathrm{F}\right)$ and typically varies from $62^{\circ} \mathrm{F}$ to $90^{\circ} \mathrm{F}$ and is rarely below $56^{\circ} \mathrm{F}$ or above $95^{\circ} \mathrm{F}$. Three hospitals in the Local Government were selected for this study which include General hospital Ikole located in Ikole, Living Well hospital located in Asin and Ogunleye hospital located in Ara (Figure 1). The three hospitals are among the frequently visited health facilities in Ikole LGA. Malaria is hyperendemic in these tropical areas due to the favourable environmental conditions. Thus, these hospitals are located in malaria endemic region to cater for the residents' health particularly for malaria control.

\section{Study Design}

A cross-sectional randomised and hospital-based study was conducted between February and October 2019 at three different hospitals namely, General hospital located in Ikole, Living Well hospital located in Asin and Ogunleye hospital located in Ara. All individuals, except pregnant women, visiting these hospitals were sampled so long they meet the criteria for inclusion which include feelings of headache, fever with temperature greater than $38^{\circ} \mathrm{C}$, questionnaires completion, submission of blood samples and readiness to give written or oral informed consent.

\section{Determination of sample size}

Overall, 300 blood samples were obtained from volunteer individuals in the study area according to sample size calculation which was computed using $50 \%$ parasite prevalence of malaria parasite study from a nearby related study using the statistical formula given by Centres for Disease Control and Prevention (CDC, 2005).

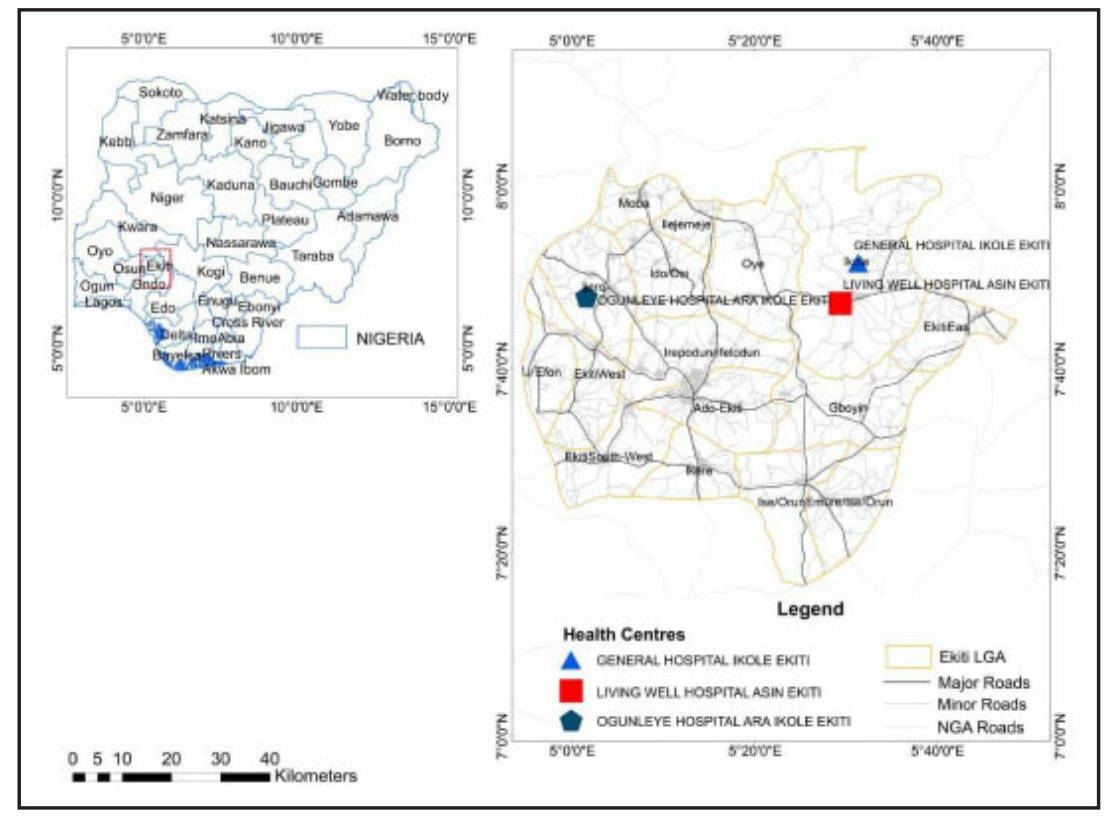

Figure 1. Map of Nigeria showing the study area in Ekiti State which include General hospital Ikole, Living Well hospital, Asin and Ogunleye hospital, Ara. 


\section{Questionnaire administration and design}

A well designed pre-tested questionnaire was administered to the participants in order to collect relevant information on their sex, age, location, occupation and education. Data was collected from the respondents via face-to-face interviews.

\section{Collection, preparation and examination of blood samples}

Blood samples were collected intravenously with the aid of an expert Laboratory Technician. A $2-3 \mathrm{~mL}$ venous blood was collected using syringe and needle. The blood samples were collected into an ethylenediaminetetraacetic acid (EDTA) tube to prevent the blood from clotting in order to preserve the samples. Thereafter, thick and thin smears were prepared on clean and well disinfected slides. The thin smear was fixed in absolute ethanol. Subsequently, 5\% Giemsa stain was added to both the thick and thin smears on the slide for 30 minutes. The slides were thereafter examined under x1000 magnification in order to determine the prevalence of Plasmodium parasites and their specific species. Each slide was considered negative when approximately 200 microscopic fields have been observed. The level of parasitaemia or parasite density was classified as low when parasitaemia is less than 1000 parasites/ $\mu \mathrm{L}$ of blood; moderate when parasitaemia is between 1000 and 9999 parasites/ $\mu \mathrm{L}$ of blood and severe when parasitaemia is greater than or equal to 10,000 parasites/ $\mu \mathrm{L}$ of blood (White, 2003; Atroosh et al., 2015). Parasite density was recorded as number of Parasite/ $\mu \mathrm{L}$ of blood, assuming an average leucocyte count of $8,000 / \mu \mathrm{L}$ of blood for an average individual (WHO, 2015).

Number of parasites counted $x$ Total White Blood Cell of $8000 / \mu \mathrm{L}$

\section{Parasite Density $=\frac{\text { Number of White Blood Cell Counted }}{\text { Num }}$}

\section{Statistical Analysis}

Data were analysed using Statistical Package for Social Science (SPSS) version 22.0. The prevalence of falciparum malaria was calculated and the difference of prevalence between age groups and sex were calculated using chi square at $95 \%$ level of confidence. The malaria parasite density was explored using one-way analysis of variance for variable with more than two categories while student's t-test was used to determine dichotomous variable. P-values less than 0.05 were considered statistically significantly.

\section{RESULTS}

A total of 300 individuals were examined which consists of $180(60 \%)$ male and $120(40 \%)$ female. A total of 100 individuals were examined in each of the three different hospitals namely, General hospital in Ikole, Living well hospital in Asin and Ogunleye hospital in Ara. Additionally, the population consists of age range 5 to 90 years with different occupational status such as traders, students, civil servants and farmers. The result showed that a total overall of 283 (94.3\%) individuals were positive while 17 (5.7\%) were negative. All infections recorded were identified to be $P$. falciparum.

The age pattern of malaria infection in the study area showed that age group 51 to 60 years have the highest malaria parasite prevalence of $100 \%$ while age group $<10$ have the lowest prevalence of $86.0 \%$ (Table 1). However, it was not statistically significant $\left(X^{2}=8.647, d f=6, P>0.05\right)$. Additionally, the sex pattern of malaria infection in the study area showed that male subjects have a higher malaria parasite prevalence of $95.0 \%$ compared to the female subjects with a lower prevalence of $93.3 \%$ as shown in Table 1 $\left(X^{2}=0.374, d f=1,(P>0.05)\right.$. In the same vein, a total mean malaria parasite density of 1455.90 parasite/ $\mu \mathrm{L}$ of blood was recorded (Table 1 ). The age group $>60$ years had the highest mean parasite density of 2092.50 parasite/ $\mu \mathrm{L}$ of blood while age group $<10$ has the lowest mean parasite density of 1044.42 parasite $/ \mu \mathrm{L}$ of blood. It was however not statistically significant $(P>0.05)$. Additionally, in relation to sex, the highest mean malaria parasite density was observed among the female subjects ( 1461.80 parasite/ $\mu \mathrm{L}$ of blood) compared to their male counterparts with lower parasite density (1450 parasite/ $\mu \mathrm{L}$ of blood). It was however not statistically significant $(P>0.05)$.

Similarly, with respect to location, a total of 100 individuals were examined in each of the three different hospitals namely, General hospital in Ikole, Living well hospital in Asin and Ogunleye hospital in Ara. Ogunleye hospital recorded the highest prevalence with $96 \%$ while Living Well hospital recorded the least prevalence with $92 \%$ (Table 2). However, there was no significant difference $P>0.05$. Furthermore, the parasitaemia classification of the study population according to sex and age is shown in Figure 2 and Figure 3 respectively. It was observed that an estimated 165 (58.30\%) of the infected individuals have low level of parasitaemia, 96 (33.92\%) have moderate level of parasitaemia while only $22(7.77 \%)$ have severe parasitaemia.

Table 1. Prevalence and density of malaria parasite with respect to sex and age group among residents of Ikole Local Government Area of Ekiti State

\begin{tabular}{|c|c|c|c|c|}
\hline Variables & No. Examined & No. Infected & Prevalence (\%) & $\begin{array}{c}\text { Mean ( } \pm \text { S.E) of Parasite Density } \\
\text { (parasite/ } \mu \mathrm{L} \text { of blood) }\end{array}$ \\
\hline \multicolumn{5}{|l|}{ Sex } \\
\hline Male & 180 & 171 & 95.0 & $1452.00 \pm 173.226$ \\
\hline Female & 120 & 112 & 93.3 & $1461.80 \pm 123.051$ \\
\hline \multicolumn{5}{|c|}{ Age Group (years) } \\
\hline$\leq 10$ & 50 & 43 & 86.0 & $1044.42 \pm 176.810$ \\
\hline $11-20$ & 76 & 72 & 94.7 & $1112.85 \pm 213.114$ \\
\hline $21-30$ & 51 & 49 & 96.1 & $1431.36 \pm 322.480$ \\
\hline $31-40$ & 42 & 40 & 95.2 & $1540.05 \pm 384.005$ \\
\hline $41-50$ & 28 & 27 & 96.4 & $1427.12 \pm 473.564$ \\
\hline $51-60$ & 14 & 14 & 100.0 & $1543.23 \pm 804.048$ \\
\hline$>60$ & 39 & 38 & 97.4 & $2092.50 \pm 446.048$ \\
\hline Total & 300 & 283 & 94.3 & $1455.90 \pm 172.480$ \\
\hline
\end{tabular}


Table 2. Prevalence of malaria parasite with respect to different location in Ikole Local Government Area of Ekiti State

\begin{tabular}{lccc}
\hline Location & No. Examined & No. Infected & Prevalence (\%) \\
\hline Ogunleye hospital, Ara & 100 & 96 & 96 \\
General hospital, Ikole & 100 & 95 & 95 \\
Living well hospital, Asin & 100 & 92 & 92 \\
Total & 300 & 283 & 94.33 \\
\hline
\end{tabular}

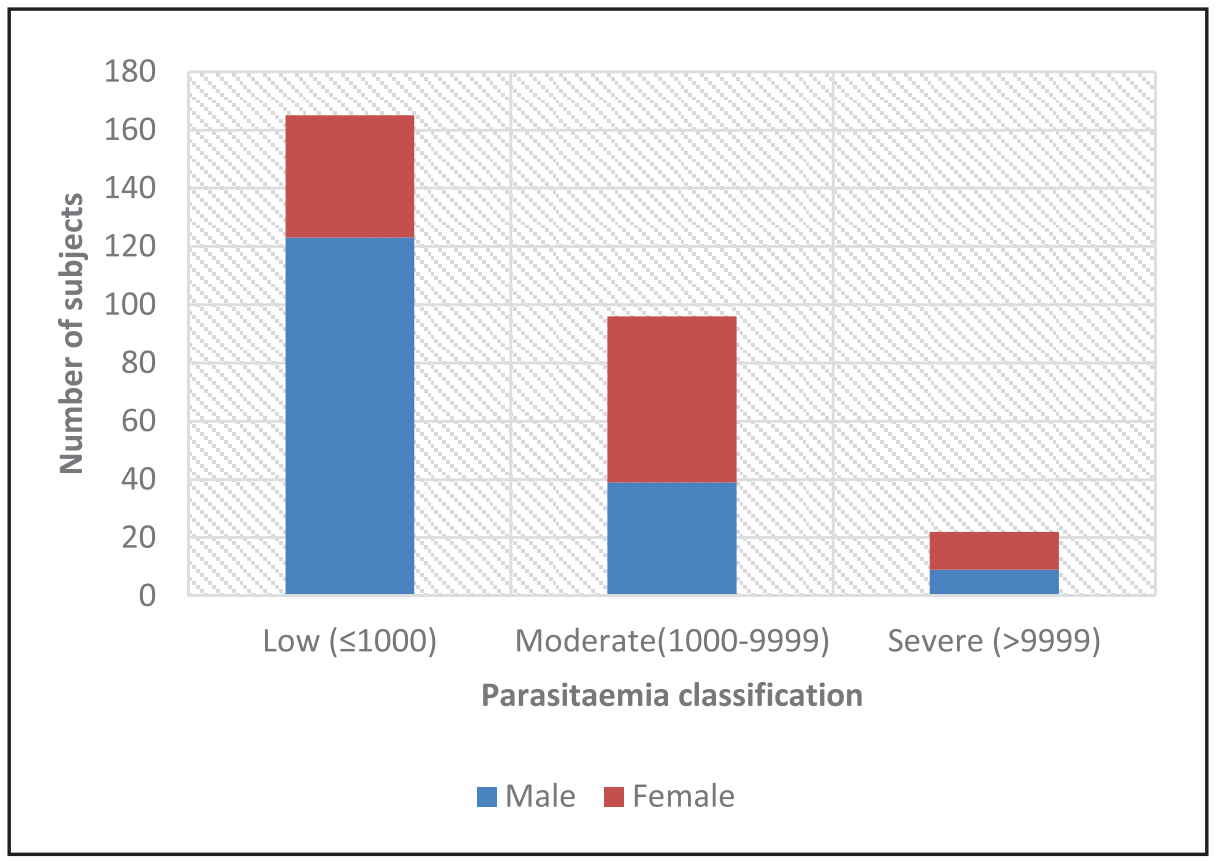

Figure 2. Parasitaemia classification of respondent among sex group in Ikole Local Government Area.

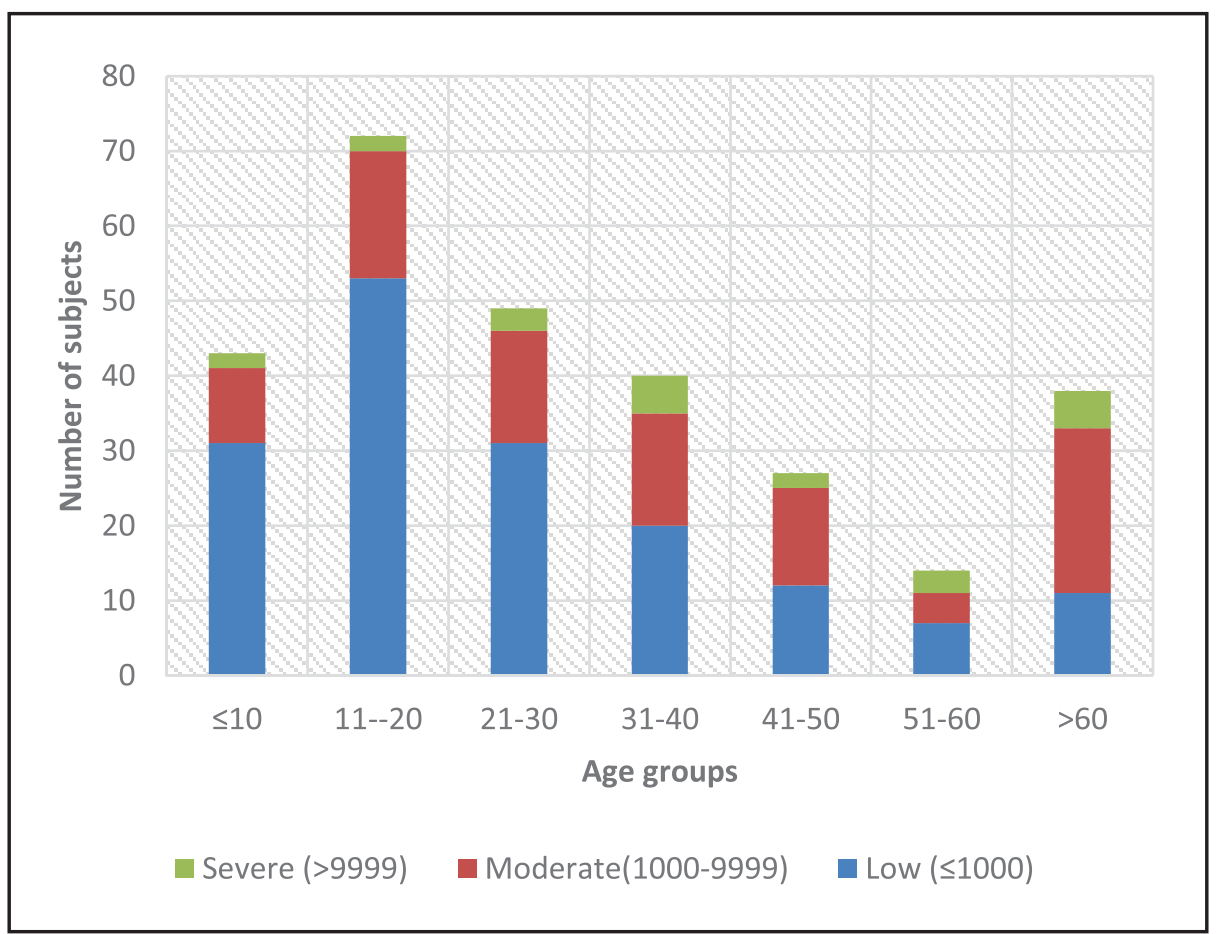

Figure 3. Parasitaemia classification of respondent among age group in Ikole Local Government Area. 
Table 3. Prevalence of malaria parasite with respect to socioeconomic variables in Ikole Local Government Area of Ekiti State

\begin{tabular}{lccc}
\hline Variables & $\begin{array}{c}\text { No. } \\
\text { Examined }\end{array}$ & $\begin{array}{c}\text { No. } \\
\text { Infected }\end{array}$ & $\begin{array}{c}\text { Prevalence } \\
(\%)\end{array}$ \\
\hline $\begin{array}{l}\text { Occupation } \\
\text { Artisans }\end{array}$ & 30 & 28 & 93.33 \\
Traders & 67 & 64 & 95.52 \\
Farmers & 115 & 113 & 98.26 \\
Students & 36 & 33 & 91.66 \\
Civil servants & 40 & 34 & 85.00 \\
Others & 12 & 11 & 91.66 \\
Education & & & \\
No Formal education & 32 & 30 & 93.75 \\
Primary education & 194 & 187 & 96.39 \\
Secondary Education & 74 & 66 & 89.18 \\
Marital Status & & & \\
$\quad$ Married & 170 & 165 & 97.05 \\
Single & 102 & 95 & 93.13 \\
Divorced & 3 & 2 & 66.66 \\
Others & 25 & 21 & 84.00 \\
Total & 300 & 283 & 94.3 \\
\hline
\end{tabular}

Moreover, prevalence of malaria parasite with respect to socioeconomic variables is presented in Table 3. Obviously, the highest falciparum malaria prevalence of $113(98.26 \%)$ was recorded among farmers while the least 34 (85\%) was recorded among Civil servants. The result was statistically significant $(P<0.05)$. In the same vein, those who had primary education had the highest malaria infection (96.39) followed by those without formal education (93.75) while the least (89.18) was observed among those who had secondary education. However, there was no significant difference $(P>0.05)$. Regarding marital status, though malaria infection was highest among those married (97.05) and was least among those who were divorced (66.66), there was no significant difference $(P>0.05)$.

\section{DISCUSSION}

Nigeria is no doubt a hot spot for malaria infection worldwide and the current study provide corroborating and supportive report. The high malaria parasite prevalence recorded is an evidence that malaria infection is endemic, and transmission is ongoing and have formed a stable pattern in Ikole Local Government Area of Ekiti State, Nigeria. The only malaria parasite species recorded in this study area was $P$. falciparum similar to the findings of studies reported from within and outside Ekiti State, Nigeria (FMOH, 2008; Simon-Oke et al., 2012; Esan et al., 2014; Nyamngee et al., 2014; Salau et al., 2016; Awosolu et al., 2019; Olorunniyi et al., 2019). In the same vein, World Health Organization has observed that most prevalent malaria parasite species in sub Saharan Africa was P. falciparum (WHO, 2003). Indeed, the high malaria parasite prevalence recorded in this study was also similar to the reports of previous studies in other parts of Nigeria (Greenwood et al., 2005; Asaolu \& Igbaakin, 2009; Okonko et al., 2009; Iwueze et al., 2014; Ayogu et al., 2016; Umma et al., 2017; Awosolu et al., 2019, 2020). However, malaria parasite prevalence in this study is greater than studies reported by Nzeako et al. (2013), Udoh et al. (2013) and Simon-Oke et al. (2019). The high malaria parasite prevalent in this current study can be attributed to the multifaceted prevailing environmental factors such as temperature, rainfall and forest cover which provide good breeding system for the mosquito vector. The more the mosquito vectors in the environment, the more the transmission and the more the malaria parasite prevalence. This could be aggravated by lack of control intervention such as insecticide treated bed net which may currently be limited in this study area (Owoseni, 2018).

Furthermore, while malaria prevalence is slightly higher though insignificant among male compared to their female counterparts, parasite density is higher among females than male. Previous studies have shown that males usually have malaria infection than females (Sachs \& Malaney, 2002; Esan, 2014; Sam Wobo et al., 2014; Adewole et al., 2017; Umma et al., 2017). Though both male and female are basically at risk of contracting malaria infection, males were generally more exposed in this study area. This could be attributed to their engagement in many activities such as farming which may expose male to mosquito bite. Other factors could be the engagement of males in businesses in dirty environments, coming back home late at night, preference to stay late outside while gathered discussing together and entertaining in an open place, carefree attitudes of males towards the use of mosquito nets and other preventive measures including treatment, common outdoor sleeping by male subjects during dry season when there is heat. All these factors have been reported to contribute to the increase in malaria prevalence among male in other study areas (Reuben et al., 1993; Rahman et al., 1996; Müller et al., 1998; Cotter et al., 2013). Thus, malaria prevention and control policies should be all-encompassing and comprehensive targeting both male and female subjects. In this study area, our findings indicated that only few females were infected with greater parasite density and health consequences compared to male subjects. This agrees with the report of Tin-Oo et al. (2001) who reported that both male and female are at risk of contracting malaria infection if they are both given the same exposure pattern to mosquito bites. However, Bates et al. (2004) showed that greater consequences of malaria infection among female subjects may occur. This implies that females are more susceptible to malaria infection than males in this study area. This could be as a result of low immunity among females as demonstrated by Duffy and Fried (2005).

In the context of our study, while the age pattern of malaria infection showed that the highest malaria prevalence of $100 \%$ was recorded among age group 51 to 60 years, it is crystal clear that malaria parasite density was highest among subjects above 60 years. This is corroborated by many studies conducted previously (Gjorup \& Ronn, 2002; Mühlberger et al., 2003; Bruneel et al., 2010; Checkley et al., 2012; WHO, 2012; Allen et al., 2016; Herrador et al., 2019). The high malaria infection among age 51 to 60 and 60 years above could be attributed to growing comorbidities as reported by Checkley et al. (2012) and Bruneel et al. (2010). When this comorbidity factor is coupled with other general risk factors contributing to exposure pattern such as staying outside late to receive fresh air during hot weather could increase odds of malaria infection and its consequences among these older age groups.

On the other hand, individuals within the age group 10 years and below have the least prevalence and intensity of malaria infection which may be as a result of care and protection against mosquito bites by their parents through the use of mosquito nets and adequate treatments. This corroborated the results of previous surveys conducted by Bonilla and Rodriguez (1993) and Manjurano et al. (2011) who stated that the ownership and proper use of mosquito bed nets is strongly linked to the prevention of the disease. 
Therefore, even though malaria infection may tend to be higher among younger children as reported by many studies (Roca-Feltrer et al., 2010; Mawili-Mboumba et al., 2013; Farnert et al., 2014; Nankabirwa et al., 2014; Ursing et al., 2014; Ceesay et al., 2015; Mathanga et al., 2015; Pinchoff et al., 2016), the use of suitable prevention and control intervention can greatly help reduce malaria among children and generally across all age and sex group.

The impact of socioeconomic factors such as occupation and education cannot be overemphasized in this study area. Those who are farmers tend to have more malaria infection compared to others. The high malaria prevalence recorded among famers in this study area is in conjunction with other previous studies (Alemu et al., 2014; Amuta et al., 2014). This could be as a result of frequent and indiscriminate exposure of these farmers to mosquito bites on the farm which eventually led to malaria infection. The use of repellent and long sleeve clothes could be employed by these farmers to prevent mosquito bites. Furthermore, our study reveals that education indirectly affected malaria distribution though there was no significant difference. Those who have primary education and those without formal education had higher malaria infection which is in agreement with the report of Essendi et al. (2019). This could be due to their low level of knowledge and awareness about malaria control and prevention. This could be addressed by increasing the level of awareness of the populace through the use of all available means including radios and televisions that could easily be understood by those who are less educated. Eventually, this would in turn gradually lead to the long-awaited dream of a malaria-free world.

\section{CONCLUSIONS}

Conclusively, malaria parasite particularly, P. falciparum is endemic and remains a leading cause of morbidity in Ekiti State and Nigeria at large. Thus, both male and female are at risk of infection in the study area. Older age group of 60 years and above are of concern as they may need special care regarding malaria infection. Farming and low level of education could be a major risk factor in the study area. Generally, a comprehensive health intervention should be deployed in the study area to mitigate local malaria transmission.

\section{ACKNOWLEDGEMENTS}

We sincerely appreciate all that voluntarily participated in this study from Ikole Ekiti Local Government Area of Ekiti State, Nigeria.

\section{Conflict of Interest}

The authors declare that no conflict of interest exist.

\section{REFERENCES}

Adewole, S.O., Odeyemi, D.F., Omotosho, O.A. \& Dada, A.O. (2017). Prevalence of malaria and treatment procurement in three local government areas of Ekiti State, Nigeria. International Journal of Scientific World 5(2): 145-147.

Alemu, K., Worku, A., Berhane, Y. \& Kumie, A. (2014). Men Traveling Away from Home Are More Likely to Bring Malaria into High Altitude Villages, Northwest Ethiopia. PLoS One 9(4): e95341. https://doi.org/10.1371/journal.pone. 0095341
Allen, N., Bergin, C. \& Kennelly, S. (2016). Malaria in the returning older traveler. Tropical Diseases, Travel Medicine and Vaccines 2: 1. https://doi.org/10.1186/s40794-0160018-9

Amuta, E., Houmsou, R., Wama, E. \& Ameh, M. (2014). Malarial Infection among Antenatal and Maternity Clinics Attendees at the Federal Medical Centre, Makurdi, Benue State, Nigeria. Infectious Disease Reports 6(1): 5050. https://doi.org/10.4081/idr.2014.5050

Asaolu, M.F. \& Igbaakin, P.A. (2009). Serum levels of micronutrients and antioxidants during malaria in pregnant women in Ado-Ekiti, Ekiti State, Nigeria. International Journal of Medicine and Medical Sciences 1(11): 523-526. https://doi.org/10.5897/IJMMS.9000216

Atroosh, W.M., Al-Mekhlaf, H.M., Al-Jasari, A., Sady, H., AlDelaimy, A.K., Nasr, N.A, Dawaki, S., Abdulsalam, A.M., Ithoi, I., Lau, Y.L., Fong, M.Y. \& Surin, J. (2015). Genetic variation of pfhrp2 in Plasmodium falciparum isolates from Yemen and the performance of HRP2-based malaria rapid diagnostic test. Parasites \& Vectors 8: 388. https://doi.org/ 10.1186/s13071-015-1008-x

Awosolu, O.B., David, M.C., Lawal, A.O. \& Ikuesan, F.A. (2019). Pattern of Malaria Parasitaemia and Genotype among Residents of Orita Obele, Akure South Local Government Area of Ondo State, Nigeria. South Asian Journal of Parasitology 3(2): 1-5.

Awosolu, O.B., Yahaya, Z.S. \& Elegbede, K.O. (2020). Prevalence of falciparum malaria parasitaemia and risk factors associated among residents of a peri urban community in Akure, Nigeria. International Journal of Advanced Science and Technology 29(7): 2165-2171.

Ayogu, E.E., Ukwe, C.C. \& Nna, E.O. (2016). Assessing the reliability of microscopy and rapid diagnostic tests in malaria diagnosis in areas with varying parasite density among older children and adult patients in Nigeria. Journal of Postgraduate Medicine 62(3): 150-156. https://doi.org/ 10.4103/0022-3859.183167

Bates, I., Fenton, C., Gruber, J., Lalloo, D., Lara, A.M., Squire, S.B., Theobald, S., Thomson, R. \& Tolhurst, R. (2004). Vulnerability to malaria, tuberculosis, and HIV/AIDS infection and disease. Part II: Determinants operating at environmental and institutional level. The Lancet Infectious Diseases 4(6): 368-75. https://doi.org/10.1016/S14733099(04)01047-3

Bonilla, E. \& Rodriguez, A. (1993). Determining malaria effects in rural Colombia. Social Science and Medicine 37(9): 11091114. https://doi.org/10.1016/0277-9536(93)90249-4

Bruneel, F., Tubach, F., Corne, P, Megarbane, B., Mira, J.P., Peytel, E., Camus, C., Schortgen, F., Azoulay, E., Cohen, Y., Georges, H., Meybeck, A., Hyvernat, H., Trouillet, J.L., Frenoy, E., Nicolet, L., Roy, C., Durand, R., Bras, L.E. \& Wolff, M. (2010). Severe imported falciparum malaria: a cohort study in 400 critically ill adults. PLoS One 5: e13236. https://doi.org/ 10.1371/journal.pone.0013236

CDC. (2005). A Manual: Measuring and Interpreting Malnutrition and Mortality. Centre for Disease Control and Prevention and World Food Programme, pp 15-107.

Ceesay, S.J., Koivogui, L., Nahum, A., Taal, M.A., Okebe, J., Affara, M., Kaman, L.E., Bohissou, F., Agbowai, C., Tolno, B.G., Amambua-Ngwa, A., Bangoura, N.F., Ahounou, D., Muhammad, A.K., Duparc, S., Hamed, K., Ubben, D., Bojang, K., Achan, J. \& D’Alessandro, U. (2015). Malaria Prevalence among Young Infants in Different Transmission Settings, Africa. Emerging Infectious Diseases 21(7): 1114-1121. https://doi.org/10.3201/eid2107.142036 
Checkley, A.M., Smith, A., Smith, V., Blaze, M., Bradley, D., Chiodini, P.L. \& Whitty, C.J. (2012). Risk factors for mortality from imported falciparum malaria in the United Kingdom over 20 years: an observational study. The British Medical Journal 344: e2116. https://doi.org/10.1136/bmj.e2116

Clark, T.D., Greenhouse, B., Njama-Meya, D., Nzarubara, B., Maiteki-Sebuguzi, C., Staedke, S.G., Seto, E., Kamya, M.R., Rosenthal, P.J. \& Dorsey, G. (2008). Factors determining the heterogeneity of malaria incidence in children in Kampala, Uganda. The Journal of Infectious Diseases 198: 393-400. https://doi.org/10.1086/589778

Cotter, C., Sturrock, H.J.W., Hsiang, M.S., Liu, J., Phillips, A.A., Hwang, J., Gueye, C.S., Fullman, N., Gosling, R.D \& Feachem, R.G.A. (2013). The changing epidemiology of malaria elimination: new strategies for new challenges. Lancet 382: 900-911. https://doi.org/10.1016/S01406736(13)60310-4

Farnert, A., Yman, V., Homann, M.V., Wandell, G., Mhoja, L., Johansson, M., Jesaja, S., Sandlund, J., Tanabe, K., Hammar, U., Bottai, M., Premji, Z.G., Björkman, A. \& Rooth, I. (2014). Epidemiology of malaria in a village in the Rufiji River Delta, Tanzania: declining transmission over 25 years revealed by different parasitological metrics. Malaria Journal 13: 459. https://doi.org/10.1186/1475-2875-13-459

Duffy, P.E. \& Fried, M. (2005). Antibodies that inhibit Plasmodium falciparum adhesion to chondroitin sulfate $\mathrm{A}$ are associated with increased birth weight and the gestational age of newborns. Infection and Immunity 71: 6620-6623. https://doi.org/10.1128/IAI.71.11.6620-6623.2003

Esan, A.J. (2014). Severity and Prevalence of Malaria Infection and Effect of Anti-Malaria Drugs on Gender Differences Using Some Haematological Parameters. International Journal of Hematological Disorders 1(1): 1-7. https://doi.org/ 10.12691/ijhd-1-1-1

Esan, A.J., Omisakin, C.T., Titilayo, O.E. \& Fasakin, K. (2014). Evaluation of severity of malaria infection and effect of anti-malaria drugs on gender differences using blood cell lines parameters. American Journal of Medical Sciences and Medicine 2(5): 89-95. https://doi.org/10.12691/ajmsm2-5-2

Essendi, W.M., Vardo-Zalik, A.M., Lo, E., Machani, M.G., Zhou, G., Githeko, A.K. \& Afrane, Y.A. (2019). Epidemiological risk factors for clinical malaria infection in the highlands of Western Kenya. Malaria Journal 18: 211. https://doi.org/ 10.1186/s12936-019-2845-4

FMOH. (2008). National Malaria Control Programme, Abuja, Nigeria. Strategic Plan 2009-2013. A Road Map for Malaria Control in Nigeria. Draft 16 June 2008. http://www.national planningcycles.org/sites/default/fles/country_docs/ Nigeria/nigeria_draft_malaria_strategic_plan_2009-2013. Accessed April 16, 2020.

Ghebreyesus, T.A., Haile, M., Witten, K.H., Getachew, A., Yohannes, M., Lindsay, S.W. \& Byass, P. (2000). Household risk factors for malaria among children in the Ethiopian highlands. Transactions of the Royal Society of Tropical Medicine and Hygiene 94: 17-21. https://doi.org/10.1016/ S0035-9203(00)90424-3

Gjorup, I.E. \& Ronn, A. (2002). Malaria in elderly nonimmune travelers. Journal of Travel Medicine 9: 91-3. https://doi.org/ 10.2310/7060.2002.21494

Greenwood, B.M., Bojag, K., Whitty, C.J. \& Targett, G.A. (2005). Malaria. The Lancet 365: 1487-1498. https://doi.org/10.1061/ S0140-6736(05)66420-3

Herrador, Z., Fernández-Martinez, B., Quesada-Cubo, V., DiazGarcia, O., Cano, R., Benito, A. \& Gómez-Barroso, D. (2019). Imported cases of malaria in Spain: observational study using nationally reported statistics and surveillance data, 2002-2015. Malaria Journal 18(1): 230. https://doi.org/ 10.1186/s12936-019-2863-2

Hiscox, A., Khammanithong, P., Kaul, S., Sananikhom, P., Luthi, R., Hill, N., Brey, P.T. \& Lindsay, S.W. (2013). Risk factors for mosquito house entry in the Lao PDR. PLoS One 8: 10. https://doi.org/10.1371/journal.pone.0062769

Iwueze, M.O., Okwusogu, M.I., Onyido, A.E., Okafor, F.C., Nwaorgu, O.C. \& Ukibe, A.E. (2014). Prevalence, intensity and clinical profile of malaria among pregnant women attending antenatal clinics in Onitsha North Local Government Area, Anambra State, Southern Nigeria. The Bioscientist 2(1): 17-9.

Manjurano, A., Okell, L., Lukindo, T., Reyburn, H., Olomi, R., Roper, C., Clark, T.G., Joseph, S., Riley, E.M. \& Drakeley, C. (2011). Association of sub-microscopic malaria parasite carriage with transmission intensity in north-eastern Tanzania. Malaria Journal 10: 370. https://doi.org/10.1186/ 1475-2875-10-370

Mathanga, D.P., Mwandama, D.A., Bauleni, A., Chisaka, J., Shah, M.P., Landman, K.Z., Lindblade, K.A. \& Steinhardt, L.C. (2015). The effectiveness of long-lasting, insecticide treated nets in a setting of pyrethroid resistance: a case-control study among febrile children 6 to 59 months of age in Machinga District, Malawi. Malaria Journal 14: 457. https://doi.org/ 10.1186/s12936-015-0961-3

Mawili-Mboumba, D.P., Bouyou Akotet, M.K., Kendjo, E., Nzamba, J., Medang, M.O., Mbina, J.R. \& Kombila, M. (2013). Increase in malaria prevalence and age of at risk population in different areas of Gabon. Malaria Journal 12: 3. https://doi.org/10.1186/1475-2875-12-3

Mühlberger, N., Jelinek, T., Behrens, R.H., Gjorup, I., Coulaud, J.P., Clerinx, J., Puente, S., Burchard, G., Gascon, G., Grobusch, M.P., Weitzel, T., Zoller, T., Kollaritsch, H., Beran, J., Iversen, J., Hatz, C., Schmid, M.L., Björkman, A., Fleischer, K., Bisoffi, Z., Guggemos, W., Knobloch, J., Matteelli, A., Schulze, M.H., Laferl, H., Kapaun, A., McWhinney, P., LopezVelez, R., Fôtkenheuer, G., Kern, P., Zieger, B.W., Kotlowski, A., Fry, G., Cuadros, J. \& Myrvang, B. (2003). Age as a risk factor for severe manifestations and fatal outcome of falciparum malaria in European patients: observations from TropNetEurop and SIMPID Surveillance Data. Clinical Infectious Diseases 36(8): 990-995. https://doi.org/10.1086/ 374224

Müller, J., Smith, T., Mellor, S., Rare, L. \& Genton, B. (1998). The effects of distance from home on attendance at a small rural health centre in Papua New Guinea. International Journal of Epidemiology 27(5): 878-884. https://doi.org/ $10.1093 / \mathrm{ije} / 27.5 .878$

Mutero, C.M., Kabutha, C., Kimani, V., Kabuage, L., Gitau, G., Ssennyonga, J., Githure, J., Muthami, L., Kaida, A., Musyoka, L., Kiarie, E. \& Oganda, M. (2004). A transdisciplinary perspective on the links between malaria and agroecosystems in Kenya. Acta Tropica 89: 171-186. https:// doi.org/10.1016/j.actatropica.2003.07.003

Nankabirwa, J., Brooker, S.J., Clarke, S.E., Fernando, D., Gitonga, C.W., Schellenberg, D. \& Greenwood, B. (2014). Malaria in school-age children in Africa: an increasingly important challenge. Tropical Medicine \& International Health 19(11): 1294-1309. https://doi.org/10.1111/tmi.12374

Nyamngee, A., Edungbola, L.D., Edogun, A.H. \& Akanbi, A.A. (2014). Malaria parasitaemia among pregnant women possessing freely donated Insecticide-Treated Nets (ITNs) in Ado-Ekiti, Nigeria. Global Journal of Biology, Agriculture and Health Sciences. 3(1): 86-91.

Nzeako, S.O., Nduka, F.O. \& Origie, O.A. (2013). Prevalence of malaria in pregnant women attending antenatal care at University of Port Harcourt Primary Healthcare Centre Aluu, 
Port Harcourt, Rivers State, Nigeria. International Journal of Scientific Research in Environmental Sciences 1(10): 263-272. https://doi.org/10.12983/ijsres-2013-p268-272

Oboh, M.A., Badiane, A.S., Ntadom, G., Ndiaye, Y.D., Diongue, K. \& Ndiaye, D. (2018). Molecular identification of Plasmodium species responsible for malaria reveals Plasmodium vivax isolates in Duffy negative individuals from southwestern Nigeria. Malaria Journal 17(1): 439. https://doi.org/10.1186/s12936-018-2588-7

Okonkwo, I.O., Soleye, F.A., Amusan, T.A., Ogun, A.A., Udeze, A.O., Nkang, A., Ejembi, J. \& Faleye T.O.C. (2009). Prevalence of Malaria Plasmodium in Abeokuta, Nigeria. Malaysian Journal of Microbiology 5(2): 113-118. http://dx.doi.org/ 10.21161/mjm.16509 113

Owoseni, J.S. (2018). An Assessment of the use of Insecticide Treated Net among under Five in Ekiti State as a Means of Prevention of Malaria. Perceptions in Reproductive Medicine. 2(3): 000544. https://doi.org/10.31031/PRM.2018. 02.000544

Olorunniyi, O.F., Idowu, O.A., Idowu, A.B., Pitan, O.R. \& Babalola, A.S. (2019). Malaria Parasite Infection in Some Periurban and Rural Communities in Ekiti State, Nigeria. Journal of Advances in Biology \& Biotechnology 22(3): 1-11. https:// doi.org/10.9734/jabb/2019/v22i330118

Pinchoff, J., Chaponda, M., Shields, T.M., Sichivula, J., Muleba, M., Mulenga, M., Kobayashi, T., Curriero, F.C. \& Moss, W.J. (2016). Individual and household level risk factors associated with malaria in Nchelenge district, a region with perennial transmission: a serial cross-sectional study from 2012 to 2015. PLoS One 11: e0156717. https:// doi.org/10.1371/journal.pone.0156717

Rahman, S.H., Mohamedani, A.A., Mirgani, E.K. \& Ibrahim, A.M. (1996). Gender aspects and women's participation in the control and management of malaria in central Sudan. Social Science \& Medicine 42: 1433-1446. https:// doi.org/10.1016/0277-9536(95)00292-8

Reuben, R. (1993). Women and Malaria - Special Risks and Appropriate Control Strategy. Social Science and Medicine 37(4): 473-480.

Roca-Feltrer, A., Carneiro, I., Smith, L., Armstrong Schellenberg, J.R., Greenwood, B. \& Schellenberg, D. (2010). The age patterns of severe malaria syndromes in sub-Saharan Africa across a range of transmission intensities and seasonality settings. Malaria Journal 9: 282. https://doi.org/ 10.1186/1475-2875-9-282

Sachs, J. \& Malaney, P. (2002). The economic and social burden of malaria. Nature 415: 680-685. https://doi.org/10.1038/ 415680a

Salau, O.R., Ewumi, T., Owolabi, B.E., Ajayi, G.O. \& Ajayi, O.E. (2016). Regional distribution of malaria in Ekiti State, Nigeria. World Scientific News 55: 89-100.

Sam Wobo, S.O., Adekunle, N.O., Adeleke, M.A., Dedeke, G.A., Oke, O.A., Abimbola, W.A. \& Surakat, O.A. (2014). Epidemiological Factors in Prevalence of Malaria Parasites in Primary Health Facilities Attendees, Ogun State, Nigeria. Malaria Chemotherapy, Control \& Elimination 3: 111. https://doi.org/10.4172/2090-2778.1000111

Simon-Oke, I.A., Afolabi, O.J. \& Olofintoye, L.K. (2012). Species abundance and monthly distribution of adult mosquito vector in Ekiti State, Nigeria. FUTA Journal of Research in Science 1: 83-88.

Simon-Oke, I.A., Ogunseemi, M.F., Afolabi, O.J. \& Awosolu, O.B. (2019). Prevalence of malaria parasites among pregnant women and children under five years in Ekiti State, Southwest Nigeria. Journal of Biomedicine and Translational Research 5(1): 5-11. https://doi.org/10.14710/ jbtr.v5i1.3711
Temu, E.A., Coleman, M., Abilio, A.P. \& Kleinschmidt, I. (2012). High prevalence of malaria in Zambezia, Mozambique: the protective effect of IRS versus increased risks due to pig-keeping and house construction. PLoS One 7: 2. https://doi.org/10.1371/journal.pone.0031409

Tin, O., Pe, T.H., Khin, T.W., Parks, W. \& Bryan, J. (2001). Gender, mosquitos and malaria: Implications for community development programs in Laputta, Myanmar. Southeastern Asian Journal Tropical Medica Public Health 32: 588-94.

Udoh, E.E., Oyo-Ita, A.E., Odey, F.A., Eyong, K.I., Oringanje, C.M., Oduwole, O.A., Okebe, J.U., Esu, E.B., Meremikwu, M.M. \& Asindi, A.A. (2013). Malariometric indices among Nigerian children in a rural setting. Malaria Research and Treatment 2013: 716805. https://doi.org/10.1155/2013/716805

Umma, I.A., Robinson, W.D., Jamilu, F.A. \& Gwarzo, G.D. (2017). Prevalence of malaria parasitaemia among febrile Nigerian children with severe malnutrition in Northwestern Nigeria. Nigerian Journal of Basic and Clinical Sciences 14: 113-116. https://doi.org/10.4103/njbcs.njbcs_29_16

Ursing, J., Rombo, L., Rodrigues, A., Aaby, P. \& Kofoed, P.E. (2014). Malaria transmission in Bissau, Guinea-Bissau between 1995 and 2012: malaria resurgence did not negatively affect mortality. PLoS One 9: e0101167. https://doi.org/ 10.1371/journal.pone.0101167

White, N.J. (2003). The management of severe falciparum malaria. American Journal of Respiratory and Critical Care Medicine 167: 673-674. https://doi.org/10.1164/rccm.2212001

World Health Organization. Malaria (Chapter 7). In: International travel and health. 2012. https://www.who.int/ ith/ITH_chapter_7.pdf. Accessed April 16, 2020.

World Health Organization. (2015). Microscopy for the detection, identification and quantification of malaria parasites on stained thick and thin blood films in research settings (version 1.0): procedure: methods manual: World Health Organization; 2015. p. 32. https:// www.who.int/tdr/publications/microscopy_detec_ ident_quantif/en/. Accessed April 16, 2020.

World Health Organization. (2016). World Malaria Report 2016. Geneva: World Health Organization; 2016. http://www. who.int/malaria/publications/world_malaria_report_ 2013/en/. Accessed April 16, 2020.

World Health Organization. (2017). World Malaria Report 2017. Geneva: World Health Organization; 2017. https://doi.org/ 10.1071/EC12504. Accessed April 16, 2020.

World Health Organization. (2018). World malaria report 2018. Geneva: World Health Organization; 2018. https://www. who.int/malaria/publications/world-malaria-report2018/en/. Accessed April 16, 2020.

World Health Organization. (2019). World malaria report 2019. Geneva: World Health Organization; 2019. https://www. who.int/publications-detail/world-malaria-report-2019. Accessed April 16, 2020.

Wielgosz, B., Kato, E. \& Ringler, C. (2014). Agro-ecology, household economics and malaria in Uganda: empirical correlations between agricultural and health outcomes. Malaria Journal 13: 11. https://doi.org/10.1186/1475-287513-251

Yeka, A., Gasasira, A., Mpimbaza, A., Achan, J., Nankabirwa, J., Nsobya, S., Staedke, S.G., Donnelly, M.J., WabwireMangen, F., Talisuna, A., Dorsey, G., Kamya, M.R. \& Rosenthal, P.J. (2012). Malaria in Uganda: challenges to control on the long road to elimination I. Epidemiology and current control efforts. Acta Tropica 121: 184-195. https://doi.org/10.1016/j.actatropica.2011.03.004 